Д.Д. Смирнова ${ }^{1}$, О.В. Усачова ${ }^{1}$, О.М. Фірюліна ${ }^{2}$

\title{
ОСОБЛИВОСТІ ПЕРЕБІГУ КОРУ В ЕПІДСЕЗОНІ 2017-2018 pp. - РОЗВИТОК АСОЦІЙОВАНОГО З ВІРУСОМ КОРУ УРАЖЕННЯ ПЕЧІНКИ
}

\author{
${ }^{1}$ Запорізький державний медичний університет, ${ }^{2}$ КУ Обласна клінічна лікарня 3ОР
}

\begin{abstract}
Мета - вивчення зв'язку гепатоцитолітичного синдрому, виявленого у хворих на кір в епідемічному сезоні 2017-2018 рр., з вірусною етіологією основного захворювання.

Матеріали і методи. Ретроспективно були вивчені історії хвороби 100 пацієнтів із встановленим діагнозом кору, які перебували на лікуванні у зОІкл в період з вересня 2017 по березень 2018 рр. Всі пацієнти, за результатами підвищення активності фрерменту аланінамінотрансферази (АЛТ), були розділені на дві групи: з підтвердженим цитолізом (Г1, $n=54)$ та 3 нормальними показниками АЛТ (Г2, n=46).
\end{abstract}

Результати досліджень та їх обговорення. Загальна кількість ускладнень кору була вища у пацієнтів Г1 (88,8 \%). Для цієї групи також була більш характерна гепатомегалія (59,3 \%). За результатами загального аналізу крові пацієнтів були визначені непрямі ознаки, що свідчать про спрямованість імунної відповіді на вірус кору. За порівнянням відношення показників лімфоцитопенія/лімфоцитоз у Г1 була виявлена сповільнена противірусна імунна реакція, на відміну від Г2. Оцінка синдрому цитолізу проводилась у порівнянні АЛТ першого біохімічного аналізу на 1-2-у добу (АЛТ-1) та повторного тесту на 5-7-у добу госпіталізаціі (АЛТ-2) у пацієнтів Г1. Було встановлено, що цитоліз легкого ступеня важкості (АЛТ>в 1-2 рази) швидко знижувався у динаміці: АЛТ-1 72,2 \% проти АЛТ-2 46,9 \%, на відміну від ураження середнього (АЛТ>2,55 разів) та важкого (АЛТ>5-10 раз) ступеня, що зберігався без значних змін і на 7-й день госпіталізації.

Висновки. Сучасна особливість кору - ураження печінки, що реєструється у $54 \%$ випадків. Розвиток реактивного гепатиту пов'язаний з прямою цитопатичною дією вірусу кору. Легкий ступінь підвищення АЛТ та його подальша нормалізація на 5-7-у добу вказують на сприятливий перебіг процесу та швидке відновлення функції органа. При розвитку реактивного гепатиту у хворих на кір сповільнюється швидкість імунної відповіді. Можливо, з цим пов'язана і більша кількість пацієнтів з бактерійними ускладненнями у Г1. Згідно з цими висновками, пацієнтів з кором та реактивним гепатитом слід відносити до групи ризику за розвитком бактерійних ускладнень.

Ключові слова: кір, реактивний гепатит, противірусний імунітет, інфекційні захворювання.

Кір - інфекційне захворювання, що передається за допомогою повітряно-крапельного механізму і має високий рівень контагіозності. Викликається РНК-параміксовірусом Polinosa morbillarum. Типова клініка включає наявність катарального періоду із симптомами інтоксикації, патогномонічний симптом Копліка, період екзантеми (характерна етапність поширення висипу). Найбільшу небезпеку становлять специфрічні ускладнення: корові енцефраліти, менінгіти, пневмонії, бронхіти.

В Україні кір регулярно реєструється у вигляді епідемічних підйомів захворюваності з проміжками в 4-5 років [1]. Незадовільне охоплення і відмови батьків від вакцинації, а також проблеми з постачанням і зберіганням препаратів для вакцинації залишаються основними причинами персистенції вірусу в середовищі та хвилеподібного перебігу епідемічного процесу [1].

Останній спалах в Україні пов'язаний з міграцією вірусу з країн східної Європи (перш за все - Румунії). Відсутність колективного імунітету дозволила патогену швидко поширитися територією держави і зберігатися протягом тривалого часу [2].

Від початку епідемії 2017 р. до другої половини 2018 р. по всій території країни зареєстровано 33189 лабораторно підтверджених випадків кору включно з 15 летальними [3]. Розвиток важких ускладнень, особливо серед пацієнтів дитячого віку, робить проблему діагностики та активної профілактики найбільш актуальною.

При обстеженні хворих, які проходили лікування 3 приводу кору в Запорізькій обласній клінічній інфекційній 


\section{ОРИГІНАЛЬНІ ДОСЛІДЖЕННЯ}

лікарні (ЗОІКЛ) в цей період, були виявлені симптоми ураження печінки: гепатомегалія та ознаки цитолітичного синдрому у пацієнтів з негативними маркерами вірусних гепатитів та без супутньої патології.

Метою дослідження було вивчення зв'язку гепатоцитолітичного синдрому, виявленого у хворих на кір в епідемічному сезоні 2017-2018 рр., з вірусною етіологією основного захворювання.

\section{Матеріали і методи}

Ретроспективно були вивчені історії хвороб пацієнтів (n=100), які перебували на лікуванні в ЗОІкЛ (гол. лікар В.Л. Шинкаренко) в період з вересня 2017 по березень 2018 рр. У дослідження послідовно включені всі хворі на кір, які були госпіталізовані в ОІКЛ у цей час.

Всі пацієнти за результатами підвищення активності фрерменту АЛт у першому біохімічному аналізі крові, проведеному в 1-2-й день від моменту ушпиталення (АЛТ-1), були розділені на дві групи:

- група 1 (Г1) - n=54 з підтвердженим цитолізом реактивний гепатит;

- група 2 (Г2) - n=46 з нормальними показниками активності Алт.

Серед загального числа обстежених 53,0 \% склали пацієнти жіночої статі і 47,0 \% - чоловічої. Середній вік склав $(16,3 \pm 13,9)$ років $(\max =51 ; \min =0,4$; IQ25-75=6,024,0). Всі пацієнти були обстежені згідно з локальними протоколами лікувального закладу III рівня надання медичної допомоги. За необхідності їм було проведено УзД органів черевної порожнини.
Статистична обробка отриманих даних проводилася за стандартними методиками з використанням програми TIBCO Statistica тм version 13.3. Обчислювали середні арисрметичні величини (М), середні квадратичні відхилення (m), а також проводили порівняльний аналіз відносних величин у групах 3 використанням критерію Пірсона $X^{2}$ макс ( $€$ статистична відмінність при $\mathrm{p} \leq 0,05)$. Для оцінки параметричних даних використовувався t-критерій Стьюдента для незалежних вибірок (є статистична відмінність при $p<0,05)$, при цьому для перевірки гіпотези про рівність двох дисперсій досліджуваних вибірок використовувався двовибірковий f-тест для дисперсій (де при р>0,05 дисперсії рівні).

\section{Результати досліджень та їх обговорення}

Аналіз отриманих результатів не виявив статистичної залежності за статевою ознакою між групами спостереження. Так само не було виявлено статистичної різниці за середнім віком пацієнтів в Г1 - $(17,03 \pm 2,02)$ років та Г2 - $(12,14 \pm 1,80)$ років $(\mathrm{p}=0,08)$.

В обох досліджених групах перебіг захворювання був типовим: у клініці відзначені патогномонічний симптом Копліка, типовий плямисто-папульозний висип 3 етапним поширенням у 100,0 \% пацієнтів обох груп.

Загальна кількість ускладнень (мал. 1) була вища у пацієнтів Г1 (n=48/54 88,8 \% проти n=34/46 73,9 \% в Г2 - $p=0,052)$, при цьому окремі нозологічні форми не виявили достовірних відмінностей: гострий бронхіт $(p=0,812)$ і пневмонія $(p=0,812)$.

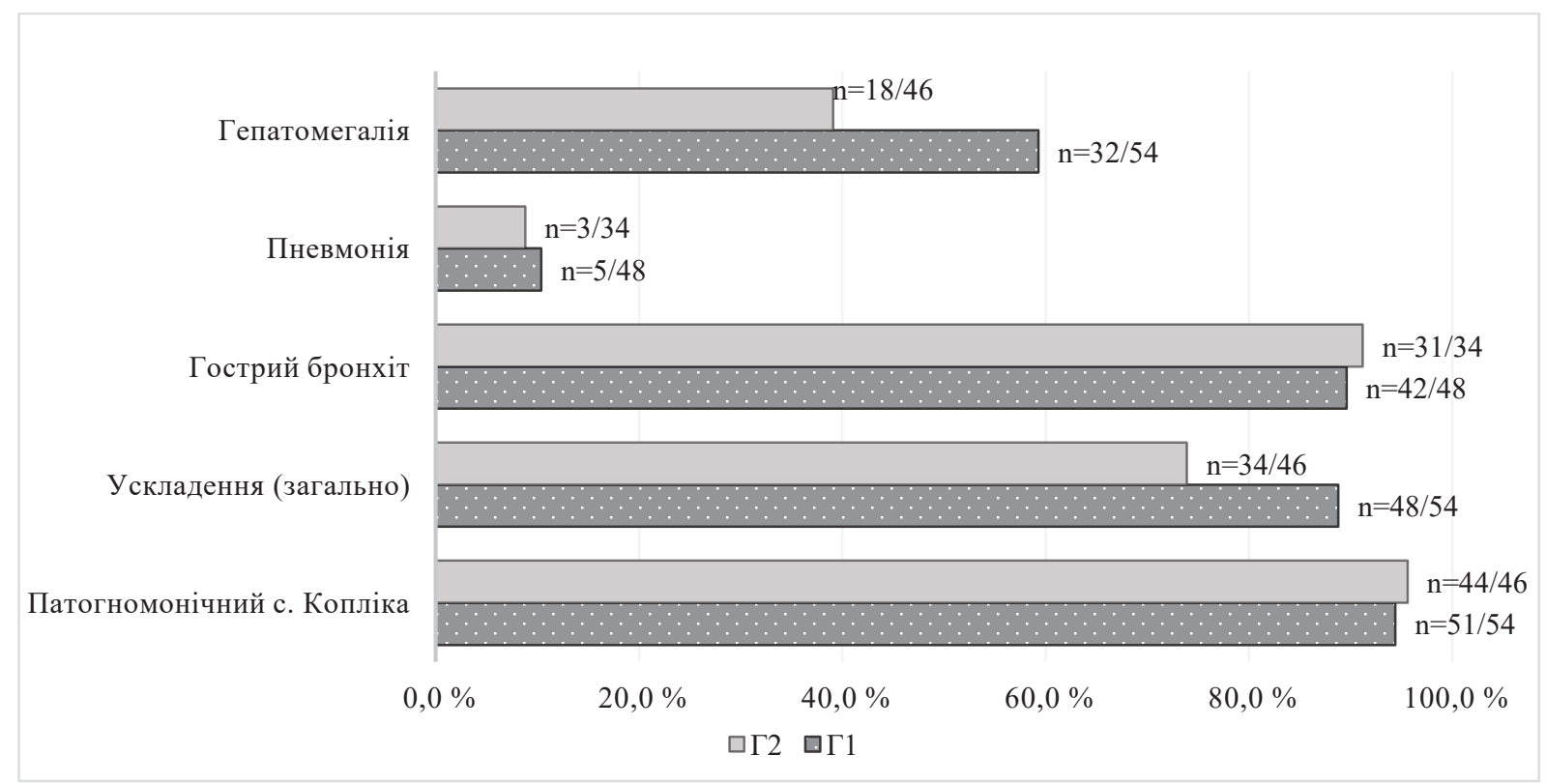

Мал. 1. Особливості клінічного перебігу кору в епідсезоні 2017-2018 рр.

Примітки (тут і далі): Г1 - група пацієнтів з гепатоцитолізом (n=54), г2 - група пацієнтів без гепатоцитолізу (n=46). 


\section{ОРИГІНАЛЬНІ ДОСЛІДЖЕННЯ}

Було встановлено, що гепатомегалія більш характерна для Г1 (n=32/54 59,3 \% пацієнтів; проти n=18/46 39,1 \%, в Г2 - (p=0,044). Слід зазначити, що збільшення печінки виникає ізольовано, без супутньої спленомегалії (Г1 n=2/54 3,7\%; Г2=0).

Далі на підставі даних клінічного аналізу крові (ЗАК1) були визначені непрямі ознаки, що свідчать про спрямованість імунної відповіді на вірусний вплив у хворих 3 реактивним гепатитом і групи контролю (мал. 2). Було встановлено, що лейкоцитопенія, як характерна лабораторна ознака кору, виявлена у більшості пацієнтів обох груп. Друга характерна ознака - від- носний лімфоцитоз - виникає у групах без статистичної різниці ЗАК-1: Г1 n=17/54 31,5\% і Г2 n=21/46 45,6 \% ( $p=0,145) ;$ проти ЗАК-2: Г1 n=21/46 62,7 \% і Г2 n=35/44 79,6 \% ( $p=0,073)$. Однак всередині Г1 помітна динаміка між зіставленням лімфоцитопенія/лімфоцитоз: ЗАК-1 $n=14 / 17(p=0,523)$ і ЗАК-2 n=2/32 (p=0,014) - статистична різниця фрормується між показниками на 3-5-у добу. Порівняння відношення лімфоцитопенія/лімфоцитоз у Г2 виявив: ЗАК-1 $n=10 / 21$ ( $p=0,015)$ і ЗАК-2 $n=2 / 35$ $(p=0,001)$ - вагома статистична різниця виявлена ще при першому аналізі крові.

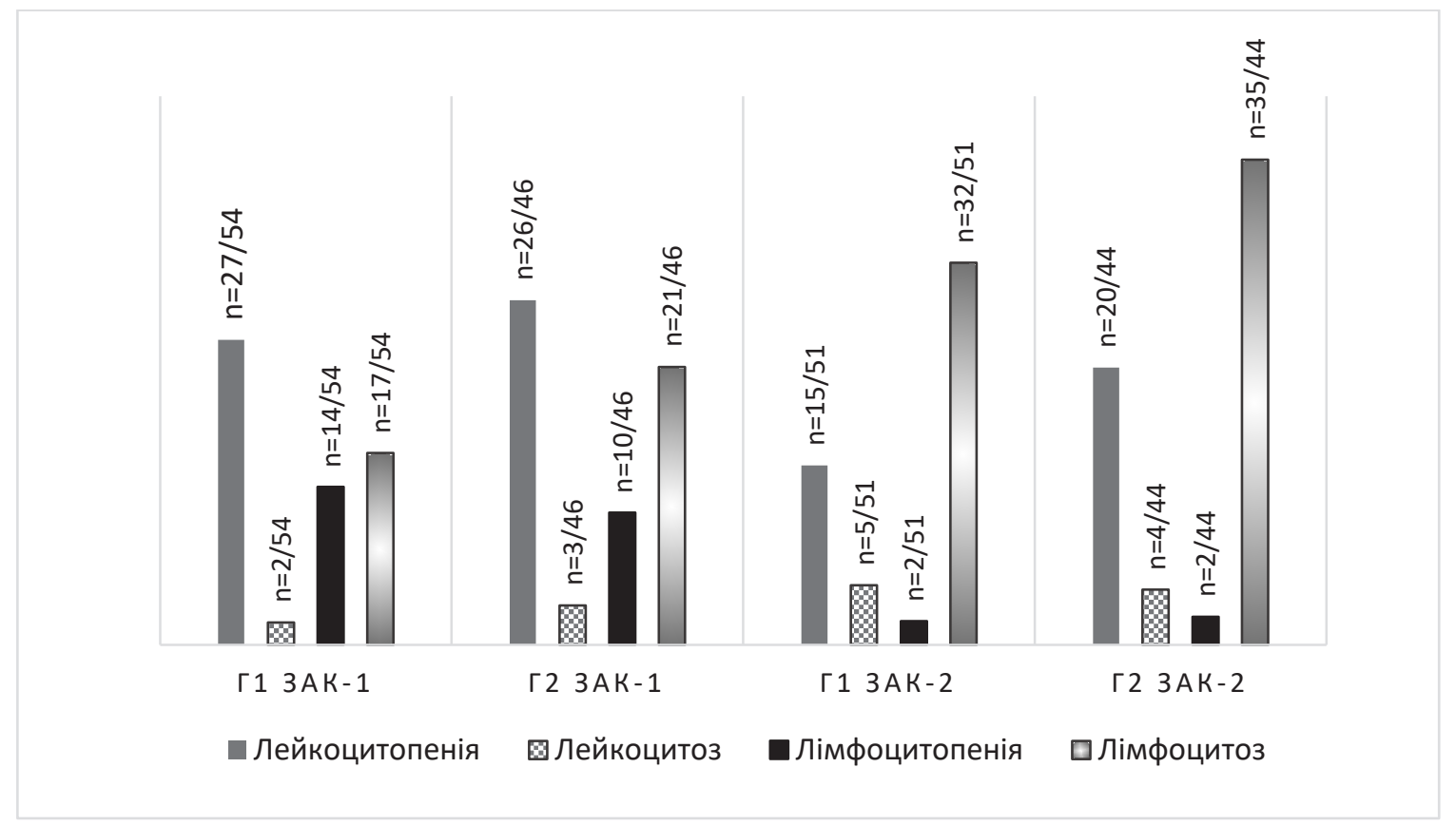

Мал. 2. Динамічні зміни показників загального аналізу крові пацієнтів груп спостереження.

Примітки: ЗАК-1 - на 1-2-у добу лікування; ЗАК-2 - на 3-5-у добу лікування.

Виявлені відмінності між групами свідчать про сповільнену противірусну імунну реакцію пацієнтів Г1, порівняно з результатами контролю.

Динамічна оцінка синдрому цитолізу в Г1 проводилась шляхом порівняння активності АЛТ у першому біохімічному аналізі на 1-2-у добу госпіталізації (АЛТ-1; норма=0,1-0,68 ммоль/год×л) і повторного аналізу на 5-7-у добу (АЛТ-2).

Для цього всі пацієнти, відповідно до ступеня важкості гепатоцитолізу, були розділені на три групи: легкого (підвищення АЛТ в 1-2 рази від норми), середнього (підвищення АЛТ в 2,5-5 разів від норми) і важкого (підвищення АЛТ в 5,5-10,0 разів від норми) ступеня.

Під час аналізу даних за критерієм Пірсона було виявлено, що рівень цитолізу легкого ступеня в динамі- ці швидко знижувався: АЛТ-1: n=39/54 72,2 \% проти АЛТ-2: $n=15 / 32$ 46,9 \% ( $p=0,018)$. Відновний період тривав не більше 7-10 днів. Повністю нормалізувався рівень ферменту в аналізі АЛТ-2 у n=9/32 28,12 \% пацієнтів, які повторно пройшли обстеження (мал. 3).

У свою чергу показники активності фрерменту пацієнтів 3 ураженням середнього ступеня (АЛТ-1: n=9/54 16,7 \%; проти АЛТ-2: $n=5 / 32$ 15,6 \%; p=0,9) і високого ступеня важкості (АЛТ-1: n=6/54 11,1 \%; проти АЛТ-2: $n=3 / 32$ 9,4\%; p=0,79) залишалися без суттєвих змін протягом 5-7 днів. У такому випадку відновний період тривав більше 10-14 днів. Надалі вони потребували диспансерного нагляду в гастроентеролога.

Слід зазначити, що більшість пацієнтів обох груп отримувала курс антибіотикотерапії у зв'язку з розвитком 
ОРИГІНАЛЬНІ ДОСЛІДЖЕННЯ

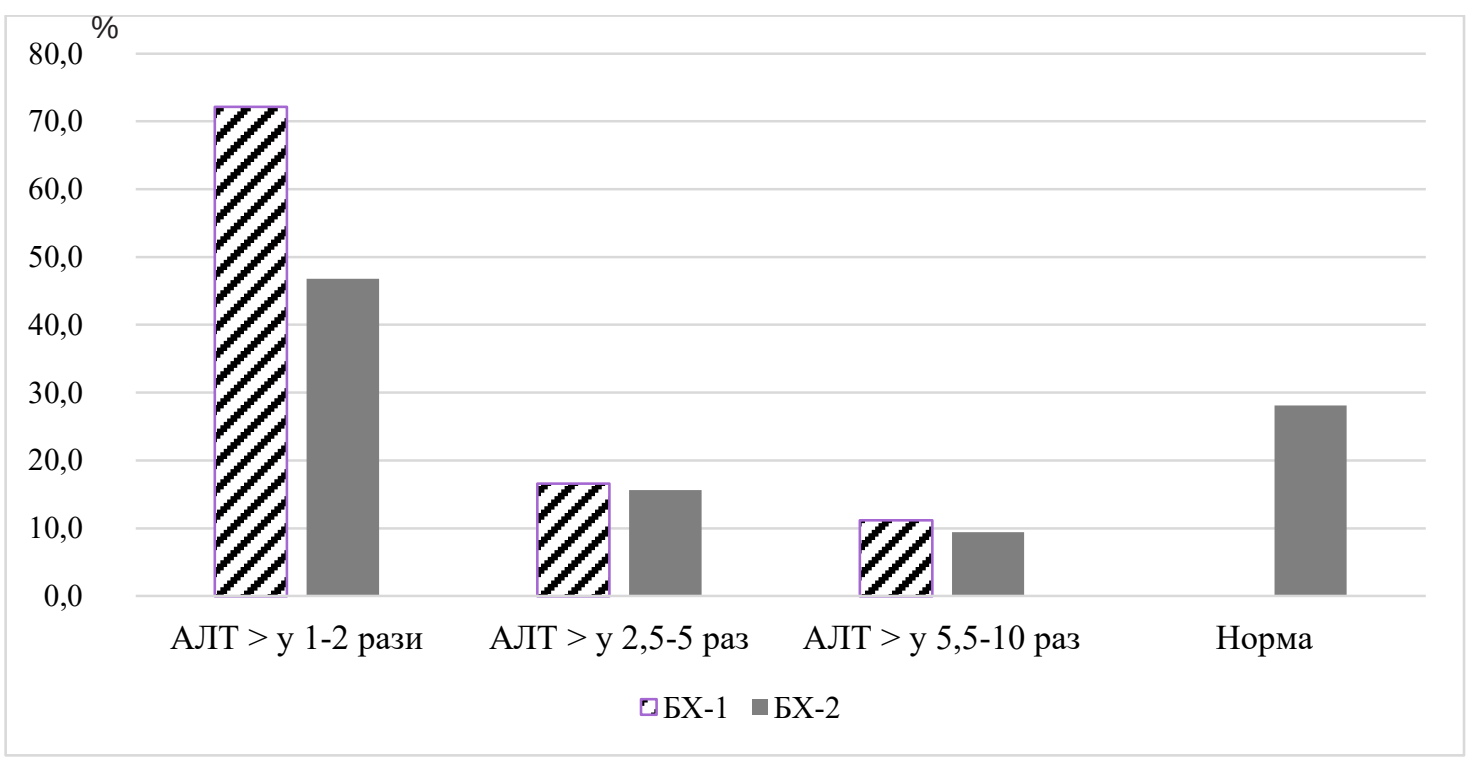

Мал. 3. Динаміка активності АЛт у пацієнтів з кором залежно від ступеня цитолітичного синдрому.

Примітки: БХ-1 - обстеження у 1-2-й день лікування (n=54), БX-2 - обстеження на 5-7-й день лікування (n=32).

бактерійних ускладнень, що могло спричинити зміни роботи печінки. Але ймовірну роль антибактерійної терапії у розвитку гепатоцитолітичного синдрому виключає як той фракт, що зміни АЛТ відзначені вже при першому дослідженні, так і те, що проведений аналіз виявив статистичну різницю у використанні цестриаксону (Г1 $\mathrm{n}=40 / 52$ 76,9 \%; Г2 n=34/36 94,4 \%; $p=0,02)$ на користь групи контролю. Це дозволяє виключити використання антибіотиків як токсичного фрактора гепатиту у пацієнтів 3 кором.

Слід зауважити, що в Г1 увійшли поодинокі пацієнти $з$ хронічними захворюваннями гепатобіліарної системи: один 3 хронічним гепатитом В (HBsAg «+», antiHBcorlgM «-», anti-HCV IgM/lgG «-») і три (6,6 \%) 3 хронічним холециститом. Однак при статистичній обробці матеріалу не було відзначено впливу цього фрактора на ступінь цитолітичного синдрому ( $>>0,05)$.

Таким чином, в епідемічному сезоні 2017-2018 pр. ми зіткнулися з відносно рідкісним ускладненням - гепатитом, який, ймовірно, був пов'язаний з безпосередньою гепатотропною дією вірусу кору. Надалі ми звернулися до літературних джерел і виявили, що під час епідемії кору 2010-2011 рр. (Париж, Франція) в університетському госпіталі Парижа було зафіксовано ускладнення кору у вигляді гепатиту (назване авторами біологічним гепатитом - biological hepatitis). Описаний синдром був поставлений на перше місце серед усіх ускладнень кору (37,5 \%), однак думки про патогенез автори не висловлювали, так само як і не проводилась оцінка ступеня гепатоцитолізу. Гепатит у всіх випадках характеризувався легким перебігом без симптомів пошкодження мезенхіми печінки [4].

Окремо Dinh A., Fleuret V., Hanslik T. проводили локальну оцінку виявлених симптомів ураження печінки (епідсезон 2010-2011рр., Париж, Франція) у 80 пацієнтів, які перебували з приводу кору у госпіталі західного Парижа. При аналізі лабораторних даних виявлено підвищення АЛт у n=65 (81,0 \%) пацієнтів, що також ставить гепатит на перше місце серед ускладнень кору. За ступенем важкості гепатоцитолізу виявлені пацієнти зі збільшенням АЛТ в 5 разів $(n=18)$ і в 10 разів $(n=5)$ понад норми. При цьому автори зазначають, що ніяких клінічних ознак (У т.ч. і гепатомегалії) у пацієнтів з реактивним гепатитом не було виявлено [5].

Раніше при проведенні дослідження щодо ураження печінки у хворих на кір (епідсезон 2001 р., місто Теджон, Південна Корея) було зафріксовано підвищення рівня АлТ переважно у «молодих» пацієнтів старше 16 років

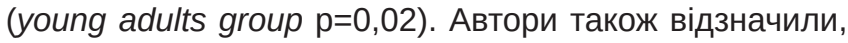
що гепатит супроводжувався асимптомним або легким перебігом без розвитку структурного ураження печінкової паренхіми [6].

Дослідження гепатиту при захворюванні на кір (епідсезон 1988 р., Єрусалим, Ізраїль) проводилось з урахуванням різних біохімічних параметрів. Автори встановили, що ураження печінки у хворих на кір - поширений симптом, що перебігає субклінічно у більшої частини пацієнтів. Порівняно мала кількість осіб мала слабкий синдром жовтяниці. Проведення одному пацієнту біопсії печінки виявило неспецифрічні, слабкі зміни у гепатоци- 
тах, асоційовані з впливом вірусу кору. У відібраних зразках вірус кору не був виявлений, що свідчить про мінімальну ступінь його інвазії в гепатоцити [7].

Все зазначене свідчить про наявність гепатопатологічного компонента у патогенезі сучасної корової інфрекції, що, вірогідно, має безпосередньо вірусну етіологію.

\section{Висновки}

1. Сучасною особливістю кору є ураження печінки, яке реєструється в 54,0 \% випадків.

2. Розвиток гепатиту, можливо, асоційований з прямою цитопатичною дією вірусу кору. Ймовірно, цю частину патогенезу слід розглядати як прояв класичної клінічної картини захворювання.

3. Гепатомегалія - симптом, що частіше асоціюється з ураженням печінки, був виявлений у пацієнтів обох груп. Збільшення печінки слід розглядати як один із симптомів безпосередньо кору, який може виявлятися як ізольовано (в Г2), так і при наявності гепатоцитолізу (в Г1).

4. Легкий ступінь підвищення АЛт і його подальша нормалізація у більшості пацієнтів на 5-у добу вказують на сприятливий перебіг процесу і швидке відновлення фрункції ураженого органа при кору.

5. В обох досліджуваних групах не було симптомів глибокого ураження структури печінки: паренхіматозна жовтяниця, печінкова енцефалопатія, зниження синтетичної фрункції та ін. Ніхто з пацієнтів не був госпіталізований у BAIT.

6. При розвитку реактивного гепатиту у хворих на кір сповільнюється швидкість імунної відповіді. Можливо, з цим пов'язано і більше число пацієнтів з бактерійними ускладненнями у Г1. Виходячи з цього, пацієнтів з кором і реактивним гепатитом слід відносити до групи ризику за розвитком бактерійних ускладнень.

\section{Література}

1. МОЗ України. Зупинити захворюваність на кір може вакцинація [Електронний ресурс]: офріційний сайт МОЗ України. - 2017. http://moz.gov.ua/.../zupiniti-zahvorjuvanist-na-kir-mozhe-vakcinacija.

2. МОЗ України. Спалах кору в Україні: що треба знати про хворобу і як захистити себе [Електронний ресурс]: офріційний сайт MO3 України. - 2018. - http://moz.gov.ua/.../spalah-koru-v-ukrainischo-treba-znati-pro-hvorobu-i-jak-zahistiti-sebe.

3. Центр громадського здоров'я МО3 України. Інфекційна захворюваність населення по Україні згідно звіту по Ф. № 1 за вересень і 9 місяців 2018-2017pp. [Електронний ресурс]: офріційний сайт Центр громадського здоров'я МОЗ України - 2018. - https:// phc.org.ua/... /infectious-morbidity-of-the-population-of-ukraine

4. French 2010-2011 measles outbreak in adults: report from a Parisian teaching hospital / M. Caseris, N. Houhou, P. Longuet [et al.] //
Clinical Microbiology and Infection. - 2014. - N 20(4). - P. 242-244. DOI: 10.1111/1469-0691.12384.

5. Dinh A. Liver involvement in adults with measles / A. Dinh, V. Fleuret, T. Hanslik // International Journal of Infectious Diseases. - 2013. - N 17(12). - P. 1243-1244. DOI: 10.1016/j.ijid.2013.06.014.

6. Clinical features of measles according to age in a measles epidemic / K.-Y. Lee, H.-S. Lee, J.-K. Hur [et al.] // Scandinavian Journal of Infectious Diseases. - 2005. - N 37 (6-7). - P. 471-475. DOI: 10.1080/00365540510037803.

7. Extent of measles hepatitis in various ages / H. Shalev-Zimels, Z. Weizman, C. Lotan [et al.] // Hepatology. - 1988. - N 8(5). P. 1138-1139. DOI: 10.1002/hep.1840080529.

\section{References}

1. (2017). Zupynyty zakhvoriuvanist na kir mozhe vaktsynatsiia [Vaccination can stop measles]. Ministry of Health of Ukraine. Retrieved from: http://moz.gov.ua/.../zupiniti-zahvorjuvanist-na-kir-mozhevakcinacija [in Ukrainian].

2. (2018). Spalakh koru v Ukraini: shcho treba znaty pro khvorobu i yak zakhystyty sebe [Measles outbreak in Ukraine: what you need to know about the disease and how to protect yourself]. Ministry of Health of Ukraine. Retrieved from: http://moz.gov.ual.../spalah-koru-vukraini-scho-treba-znati-pro-hvorobu-i-jak-zahistiti-sebe [in Ukrainian]

3. (2018). Infektsiina zakhvoriuvanist naselennia po Ukraini zhidno zvitu po F.N1 za veresen i 9 misiatsiv 2018-2017rr. [Infectious morbidity of the population in Ukraine according to the report on F.1 for September and 9 months of 2018-2017]. Center of Public Health of the Ministry of Health of Ukraine. Retrieved from: https://phc.org. ua/... /infectious-morbidity-of-the-population-of-ukraine [in Ukrainian].
4. Caseris, M., Houhou, H., Longuet, P., Rioux, C., Lepeule, R., ... Joly, V. (2014). French 2010-2011 measles outbreak in adults: report from a Parisian teaching. Clinical Microbiology and Infection., 20 (4), 242-244. DOI: 10.1111/1469-0691.12384.

5. Dinh, A., Fleuret, V., Hanslik, T. (2013). Liver involvement in adults with measles. International Journal of Infectious Diseases, 17 (12), 1243-1244. DOI: 10.1016/j.ijid.2013.06.014.

6. Lee, K.-Y., Lee, H.-S., Hur, J.-K., Kang, J.-H., \& Lee, B.-C. (2005). Clinical features of measles according to age in a measles epidemic. Scandinavian Journal of Infectious Diseases, 37 (6-7), 471-475. DOI: 10.1080/00365540510037803.

7. Shalev-Zimels, H., Weizman, Z., Lotan, C., Gavish, D., Ackerman, Z., Morag, A. (1988). Extent of measles hepatitis in various ages. Hepatology, 8 (5), 1138-1139. DOI: 10.1002/hep.1840080529. 


\section{FEATURES OF EPIDEMIOLOGICAL SEASON 2017-2018 - DEVELOPMENT OF LIVER LESION ASSOCIATED WITH MEASLES VIRUS}

D.D. Smyrnova ${ }^{1}$, O.V. Usachova ${ }^{1}$, O.M. Firulina ${ }^{2}$

${ }^{1}$ Zaporizhzhia State Medical University

2Zaporizhzhia Regional Infectious Disease Hospital

SUMMARY. The aim - to study the connection of hepatotoxicity syndrome, found in patients with measles in the epidemic season 2017-2018, with the viral etiology of the underlying disease.

Materials and methods. We retrospectively collected 100 clinical cases with approved measles diagnosis. Patients were hospitalized in Zaporizhzhia Regional Infectious Disease Hospital during September 2017 March 2018. Data were distinguished in two study groups based on activity of alanineaminotransferase $(A L T)$. Group 1(G1) with laboratory approved reactive hepatitis were privilege $54 \%$ and $46 \%$ control group 2(G2).

Results and discussion. General amount of complications was higher in study G1 (88.8\%) as well as level revealed hepatomegaly (59.3\%). According to general blood count results were observed undirected signs of inadequate immune response associated with measles virus lesion. In contradistinction based on level lympocytopenia/lymphocytosis ratio was revealed retarded immune reaction in G1 compered to G2. Cytolisis syndrome was assessed between first blood testing (ALT-1 was taken on 1-2 day) and repeat one (ALT-2 which was taken on 5-7 day). We established that mild ALT increase (ALT>in 1-2 times) was easily reversible in dynamic: $A L T-172.2 \%$ compared to $A L T-2$ $46.9 \%$. On the other hand, middle (ALT>in 2.5-5 times) and sever (ALT>in 5-10 times) lesions persisted without significant changes for more than 7 days.

Conclusions. Modern measles singularity - liver lesion which is registered in $54 \%$ cases. Reactive hepatitis development associated with direct cytopathic activity of the virus. Mild ALT increase and its following normalization point at favorable outcome and fast recovery of liver function. In addition, in patients with reactive hepatitis was detected rerated immune response rate. These processes could be connected with greater amount of bacterial complications in study G1. According to aforementioned statements patients with measles virus lesion and reactive hepatitis development have to be consider as risk group in bacterial complications development.

Key words: measles; reactive hepatitis; antiviral immunity; infection disease.

\section{Відомості про авторів:}

Смирнова Дар'я Дмитрівна - студентка 6 курсу, 1-го медичного фракультету Запорізького державного медичного університету (ЗДМУ); e-mail: heart.brain96@gmail.com

Усачова Олена Віталіївна - д.м.н., професор, завідувачка кафедри дитячих інфрекційних хвороб ЗДМУ; e-mail: kdibzsmu@gmail.com

Фірюліна Ольга Михайлівна - завідувачка першого діагностичного відділення КУ «Обласна клінічна лікарня 3ОР»; kdibzsmu@gmail.com

\section{Information about authors:}

Smyrnova D.D. - 6th year student of the Medical Faculty No. 1 of Zaporizhzhia State Medical University (ZSMU); e-mail: heart.brain96@gmail.com

Usachova O.V. - Doctor of Medicine, Professor, Head of the Department of Children's Infectious Diseases of ZSMU; e-mail: kdibzsmu@gmail.com

Firiulina O.M. - Head of the Diagnostic Department No. 1 of Regional Clinical Hospital of Zaporizhzhia Regional Council; e-mail: kdibzsmu@gmail.com

Конорлікт інтересів: немає.

Authors have no conflict of interest to declare.

Отримано 8.01.2019 р. 